Brit. J. prev. soc. Med. (1967), 21, 159-162

\title{
HEIGHTS AND WEIGHTS OF ADULTS IN RURAL AND INDUSTRIAL AREAS OF SOUTH WALES
}

\author{
BY \\ M. T. ASHCROFT, H. G. LOVELL, W. E. MIALL, AND F. MOORE \\ Medical Research Council Epidemiological Research Units, University of the West Indies, Kingston, Jamaica, \\ and Cardiff, Wales
}

Although surveys of stature, especially of weight, provide useful information on the general health of a population, there is a lack of recent anthropometric publications from Britain. The results of the national survey taken in 1943 (Kemsley, 1950) are unlikely to reflect present conditions. Here recorded are the results of surveys of heights and weights of Welsh adults living in the Vale of Glamorgan, a rural area, in 1956, and in the Rhondda Fach, a coal-mining district, in 1958.

\section{Populations and Methods}

The centres of the two areas are only 15 miles apart but the populations differ considerably. The Rhondda Fach is a typical Welsh mining valley with poor but improving housing conditions; the unemployment and poverty experienced during the great depression of the 1930s are well remembered. The part of the Vale of Glamorgan which was studied is a rural area bounded on the south by the sea, on the east by Cardiff, and on the west by Bridgend, and extending about 10 miles inland to the north. The main employment is in agriculture but some people work in Cardiff and Bridgend; occupations are more varied and living standards are higher than in the Rhondda Fach and the area had suffered less during the depression.

The surveys were designed to investigate the familial factors in blood pressure, but heights and weights were also recorded (Miall and Oldham, 1955, 1958, 1963). A private census was carried out before the first survey in each area. A sample of persons over 5 years old was drawn from the 23,900 subjects over this age in the Rhondda Fach, and another from 5,700 in the Vale. These randomly selected, stratified samples formed the index cases (propositi) for the genetic studies. As many as possible of their firstdegree relatives over 5 years of age were also examined; relatives were included if they lived within an area of about 25 miles. Though the overwhelming majority of relatives of the Rhondda Fach propositi lived in that or neighbouring mining valleys, some lived in Cardiff and a few in nearby rural areas. Similarly, though most relatives of Vale of Glamorgan propositi inhabited the Vale, some lived in Cardiff and Bridgend and a few in the mining valleys.

Subjects were visited in their homes. Heights were obtained using a graduated measuring-rod with a sliding head-piece. Weights were measured on bathroom scales which were frequently checked with standard weights. Clothes were worn except for shoes and men's jackets. All measurements were made by one person (F.M.) using the same technique and type of equipment at each survey.

The first survey of the Rhondda Fach was carried out in 1954 but because measurements of stature were obtained only from propositi those made at the second survey in 1958, when all subjects were measured, have been used. The subjects whose measurements are considered were at least 15 and not more than 80 years old in 1954 and were therefore at least 19 years old in 1958. In the Vale, the first survey measurements in 1956 of those aged from 20 to 80 years have been used. For the overall analysis, including the blood pressure data, subjects had been divided into 5-year age groups according to their ages at the first surveys and for simplicity this grouping has been retained.

Measurements of 900 persons in the Rhondda Fach and of 1,067 in the Vale were analysed; 20 per cent. in the Rhondda Fach and 24 per cent. in the Vale were propositi and the rest were their firstdegree relatives. 


\section{RESULTS}

Mean weights (lb.) and mean heights (in.) of the various age groups of men and women in the Rhondda Fach in 1958 and the Vale of Glamorgan in 1956 are shown in Tables I and II. In Figs 1 to 4 most results are combined in 10-year age groups but the youngest age group in each population and the

TABLE I

MEAN HEIGHTS AND WEIGHTS OF ADULTS IN RHONDDA FACH IN 1958

\begin{tabular}{|c|c|c|c|c|c|c|}
\hline Sex & $\begin{array}{c}\text { Mean } \\
\text { Age (yrs) }\end{array}$ & $\begin{array}{c}\text { No. of } \\
\text { Subjects }\end{array}$ & $\begin{array}{l}\text { Mean } \\
\text { Height } \\
\text { (in.) }\end{array}$ & S.D. & $\begin{array}{c}\text { Mean } \\
\text { Weight } \\
\text { (lb.) }\end{array}$ & S.D. \\
\hline Male & $\begin{array}{l}21 \cdot 2 \\
26 \cdot 9 \\
31 \cdot 9 \\
36 \cdot 5 \\
41 \cdot 9 \\
46 \cdot 2 \\
51 \cdot 4 \\
56 \cdot 4 \\
61 \cdot 5 \\
66 \cdot 2 \\
71 \cdot 4 \\
75 \cdot 6 \\
80 \cdot 6\end{array}$ & $\begin{array}{l}45 \\
38 \\
40 \\
53 \\
47 \\
38 \\
43 \\
37 \\
25 \\
28 \\
17 \\
8 \\
8\end{array}$ & $\begin{array}{l}67 \cdot 7 \\
66 \cdot 9 \\
66 \cdot 5 \\
66 \cdot 6 \\
66 \cdot 4 \\
66 \cdot 1 \\
65 \cdot 5 \\
65 \cdot 7 \\
64 \cdot 5 \\
64 \cdot 9 \\
64 \cdot 7 \\
65 \cdot 2 \\
64 \cdot 7\end{array}$ & $\begin{array}{l}2 \cdot 7 \\
2 \cdot 3 \\
2 \cdot 3 \\
2 \cdot 1 \\
2 \cdot 7 \\
2 \cdot 6 \\
2 \cdot 4 \\
2 \cdot 7 \\
1 \cdot 5 \\
2 \cdot 1 \\
3 \cdot 2 \\
3 \cdot 9 \\
2 \cdot 4\end{array}$ & $\begin{array}{l}143 \cdot 2 \\
147 \cdot 8 \\
145 \cdot 8 \\
149 \cdot 2 \\
150 \cdot 8 \\
153 \cdot 5 \\
144 \cdot 3 \\
149 \cdot 3 \\
146 \cdot 3 \\
142 \cdot 3 \\
140 \cdot 7 \\
135 \cdot 9 \\
149 \cdot 2\end{array}$ & $\begin{array}{l}20 \cdot 3 \\
23 \cdot 0 \\
17 \cdot 9 \\
21 \cdot 0 \\
19 \cdot 6 \\
20 \cdot 3 \\
25 \cdot 7 \\
26 \cdot 9 \\
24 \cdot 7 \\
19 \cdot 4 \\
25 \cdot 5 \\
13 \cdot 6 \\
25 \cdot 6\end{array}$ \\
\hline Female & $\begin{array}{l}21 \cdot 5 \\
26 \cdot 5 \\
31 \cdot 9 \\
36 \cdot 4 \\
41 \cdot 9 \\
46 \cdot 2 \\
51 \cdot 1 \\
56 \cdot 5 \\
61 \cdot 5 \\
65 \cdot 9 \\
71 \cdot 7 \\
76 \cdot 5 \\
82 \cdot 4\end{array}$ & $\begin{array}{l}45 \\
50 \\
43 \\
63 \\
55 \\
50 \\
37 \\
37 \\
37 \\
22 \\
19 \\
8 \\
7\end{array}$ & $\begin{array}{l}62 \cdot 1 \\
62 \cdot 3 \\
62 \cdot 4 \\
62 \cdot 2 \\
61 \cdot 6 \\
60 \cdot 7 \\
60 \cdot 8 \\
60 \cdot 5 \\
60 \cdot 6 \\
60 \cdot 4 \\
59 \cdot 8 \\
58 \cdot 3 \\
58 \cdot 8\end{array}$ & $\begin{array}{l}1 \cdot 8 \\
2 \cdot 1 \\
1 \cdot 8 \\
2 \cdot 2 \\
2 \cdot 1 \\
2 \cdot 4 \\
2 \cdot 3 \\
2 \cdot 7 \\
2 \cdot 2 \\
2 \cdot 4 \\
2 \cdot 5 \\
3 \cdot 2 \\
1 \cdot 6\end{array}$ & $\begin{array}{l}122 \cdot 2 \\
130 \cdot 9 \\
130 \cdot 5 \\
132 \cdot 9 \\
136 \cdot 5 \\
146 \cdot 3 \\
145 \cdot 1 \\
155 \cdot 6 \\
152 \cdot 2 \\
154 \cdot 3 \\
153 \cdot 6 \\
140 \cdot 5 \\
123 \cdot 7\end{array}$ & $\begin{array}{l}16 \cdot 3 \\
25 \cdot 3 \\
20 \cdot 2 \\
28 \cdot 7 \\
26 \cdot 8 \\
33 \cdot 5 \\
37 \cdot 5 \\
39 \cdot 3 \\
32 \cdot 2 \\
27 \cdot 5 \\
31 \cdot 7 \\
34 \cdot 7 \\
20 \cdot 2\end{array}$ \\
\hline
\end{tabular}

TABLE II

MEAN HEIGHTS AND WEIGHTS OF ADULTS IN VALE OF GLAMORGAN IN 1956

\begin{tabular}{|c|c|c|c|c|c|c|}
\hline Sex & $\begin{array}{c}\text { Mean } \\
\text { Age (yrs) }\end{array}$ & $\begin{array}{l}\text { No. of } \\
\text { Subjects }\end{array}$ & $\begin{array}{l}\text { Mean } \\
\text { Height } \\
\text { (in.) }\end{array}$ & S.D. & $\begin{array}{l}\text { Mean } \\
\text { Weight } \\
\text { (lb.) }\end{array}$ & S.D. \\
\hline Male & $\begin{array}{l}22 \cdot 2 \\
27 \cdot 6 \\
32 \cdot 7 \\
37 \cdot 5 \\
42 \cdot 3 \\
47 \cdot 3 \\
52 \cdot 1 \\
57 \cdot 1 \\
62 \cdot 4 \\
67 \cdot 7 \\
72 \cdot 1 \\
77 \cdot 4\end{array}$ & $\begin{array}{l}25 \\
43 \\
68 \\
69 \\
72 \\
73 \\
55 \\
37 \\
22 \\
32 \\
27 \\
15\end{array}$ & $\begin{array}{l}68 \cdot 0 \\
67 \cdot 4 \\
66 \cdot 9 \\
67 \cdot 1 \\
67 \cdot 0 \\
66 \cdot 7 \\
66 \cdot 3 \\
66 \cdot 0 \\
65 \cdot 8 \\
65 \cdot 2 \\
64 \cdot 0 \\
65 \cdot 3\end{array}$ & $\begin{array}{l}2 \cdot 9 \\
2 \cdot 4 \\
2 \cdot 7 \\
2 \cdot 5 \\
3 \cdot 1 \\
2 \cdot 3 \\
3 \cdot 4 \\
2 \cdot 7 \\
3 \cdot 4 \\
4 \cdot 2 \\
2 \cdot 3 \\
2 \cdot 8\end{array}$ & $\begin{array}{l}156 \cdot 3 \\
155 \cdot 1 \\
159 \cdot 9 \\
160 \cdot 2 \\
166 \cdot 2 \\
164 \cdot 3 \\
155 \cdot 4 \\
157 \cdot 4 \\
156 \cdot 2 \\
155 \cdot 0 \\
148 \cdot 0 \\
158 \cdot 7\end{array}$ & $\begin{array}{l}29 \cdot 6 \\
20 \cdot 7 \\
30 \cdot 6 \\
22 \cdot 7 \\
22 \cdot 1 \\
29 \cdot 2 \\
28 \cdot 5 \\
26 \cdot 6 \\
31 \cdot 7 \\
25 \cdot 7 \\
29 \cdot 2 \\
31 \cdot 5\end{array}$ \\
\hline Female & $\begin{array}{l}22 \cdot 3 \\
27 \cdot 4 \\
32 \cdot 7 \\
37 \cdot 5 \\
42 \cdot 8 \\
47 \cdot 5 \\
52 \cdot 6 \\
57 \cdot 2 \\
62 \cdot 4 \\
67 \cdot 4 \\
72 \cdot 4 \\
77 \cdot 7\end{array}$ & $\begin{array}{l}30 \\
48 \\
69 \\
51 \\
64 \\
64 \\
40 \\
47 \\
40 \\
30 \\
27 \\
19\end{array}$ & $\begin{array}{l}62 \cdot 9 \\
63 \cdot 4 \\
62 \cdot 7 \\
62 \cdot 4 \\
62 \cdot 3 \\
62 \cdot 4 \\
61 \cdot 9 \\
61 \cdot 7 \\
61 \cdot 7 \\
60 \cdot 3 \\
59 \cdot 7 \\
60 \cdot 1\end{array}$ & $\begin{array}{l}2 \cdot 7 \\
2 \cdot 4 \\
2 \cdot 2 \\
2 \cdot 0 \\
2 \cdot 1 \\
2 \cdot 7 \\
2 \cdot 0 \\
2 \cdot 0 \\
2 \cdot 5 \\
2 \cdot 0 \\
2 \cdot 2 \\
1 \cdot 8\end{array}$ & $\begin{array}{l}126 \cdot 9 \\
137 \cdot 4 \\
132 \cdot 7 \\
141 \cdot 0 \\
135 \cdot 3 \\
141 \cdot 6 \\
143 \cdot 3 \\
148 \cdot 6 \\
143 \cdot 4 \\
139 \cdot 8 \\
140 \cdot 0 \\
137 \cdot 1\end{array}$ & $\begin{array}{l}21 \cdot 9 \\
24 \cdot 0 \\
29 \cdot 6 \\
27 \cdot 0 \\
20 \cdot 5 \\
24 \cdot 7 \\
26 \cdot 3 \\
23 \cdot 8 \\
28 \cdot 4 \\
39 \cdot 4 \\
26 \cdot 8 \\
34 \cdot 1\end{array}$ \\
\hline
\end{tabular}

oldest in the Vale retain the 5-year grouping. For the $\frac{\pi}{3}$ Rhondda and the Vale the nude weights were $\stackrel{\mathbb{D}}{\circ}$ estimated by subtracting $3 \mathrm{lb}$. from the mean weights of the males and $2 \mathrm{lb}$. from the mean weights of the females.

\section{Discussion}

The subjects measured were not completely representative of the communities because the relatives of propositi were not randomly selected and. the Rhondda Fach subjects were those who survived $\overrightarrow{\vec{\omega}}$ 4 years between the first and second surveys. $\omega$ Nevertheless we do not think the results are likely to $\frac{\mathbb{D}}{8}$ differ appreciably from those which would have been $\stackrel{?}{?}$ obtained with truly random samples.

In Figs 1 to 4 mean heights and mean estimated + nude weights by age of American, British, Rhondda $\vec{T}$ Fach, and Vale of Glamorgan subjects are compared. The American results were based on a national 5 probability sample of 6,672 persons aged 18 to $79 \vec{~}$ years who were examined between 1959 and 1962 (U.S. Department of Health, Education, and $\frac{0}{6}$ Welfare, 1965). The British national survey was $\stackrel{\Phi}{-}$ carried out in 1943 during the war by the Minist $\overrightarrow{0}$ of Food, and was reported by Kemsley (1950. Heights and weights were measured in a sample about 61,000 men and women aged 14 to 79 years the civilian population employed in industry in selected areas of England, Wales, and Scotland. As the large numbers on military service and those not $\frac{O}{D}$ employed in industry were excluded, the sample was not truly representative of Great Britain.

A comparison of the mean heights shows that men and women in the Rhondda Fach resembled those in the British sample in 1943 except that the youngest groups of the Rhondda men were taller and the older $\bar{\alpha}$ women were slightly shorter. At most ages Vale of ? Glamorgan subjects of both sexes were between $\frac{1}{2}$ in. $\frac{5}{3}$ and 1 in. taller than those in the Rhondda Fach. American men were about $1 \frac{3}{4}$ in. and American women about 1 in. taller than those in the Vale.

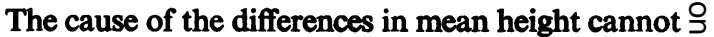
be exactly specified. It is now well established that $\frac{}{2}$ height potential may not be achieved in an adverse environment (Tanner, 1962) and the order of tallness $N$ in the populations may reflect the relative order of living standards; conditions in the Vale were better $N$ than in the Rhondda Fach and presumably less good $\mathrm{W}$ than in the U.S.A. Environment may not be the sole factor involved, however, because the racial composi- $\circ$ tions of the populations are not identical. Differential $\Phi$ migration is another factor which cannot be dis-? regarded in the small Welsh populations although it $\frac{T}{T}$ can have little effect on results of national surveys. 


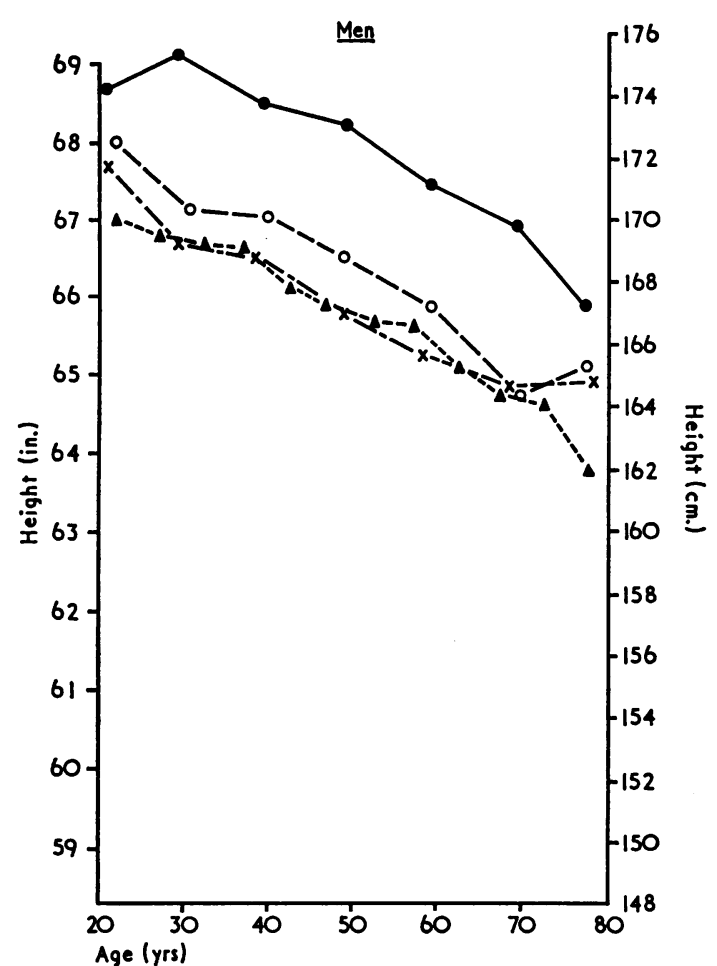

FIG. 1.- Mean heights by age of men in the Vale of Glamorgan (1956), the Rhondda Fach (1958), Great Britain (1943), and U.S.A. (1960-2).

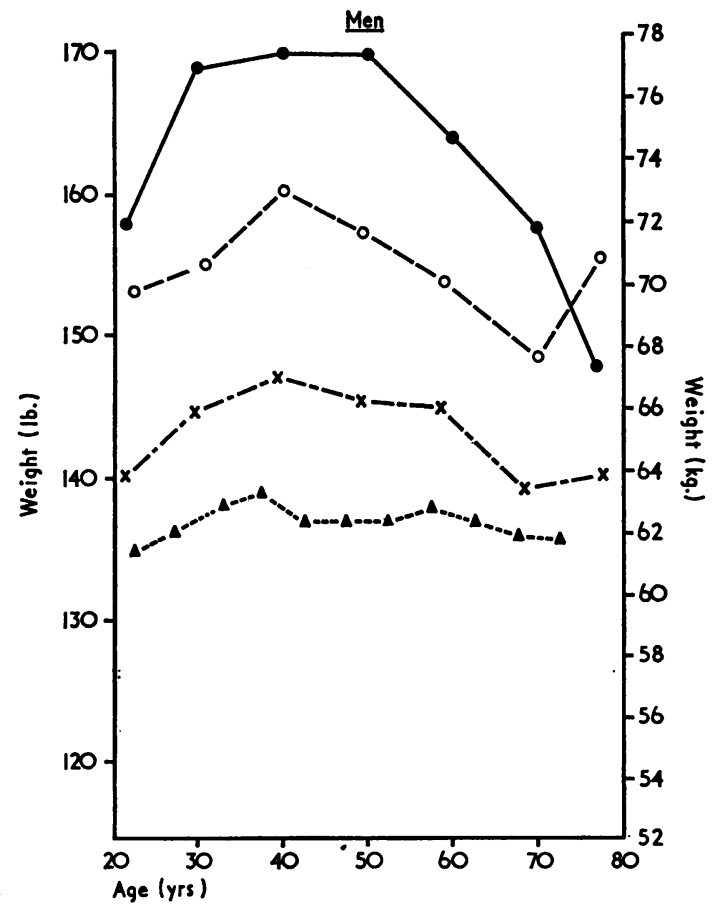

Fig. 3.-Mean weights by age of men in the Vale of Glamorgan (1956), the Rhondda Fach (1958), Great Britain (1943), and U.S.A. (1960-2).

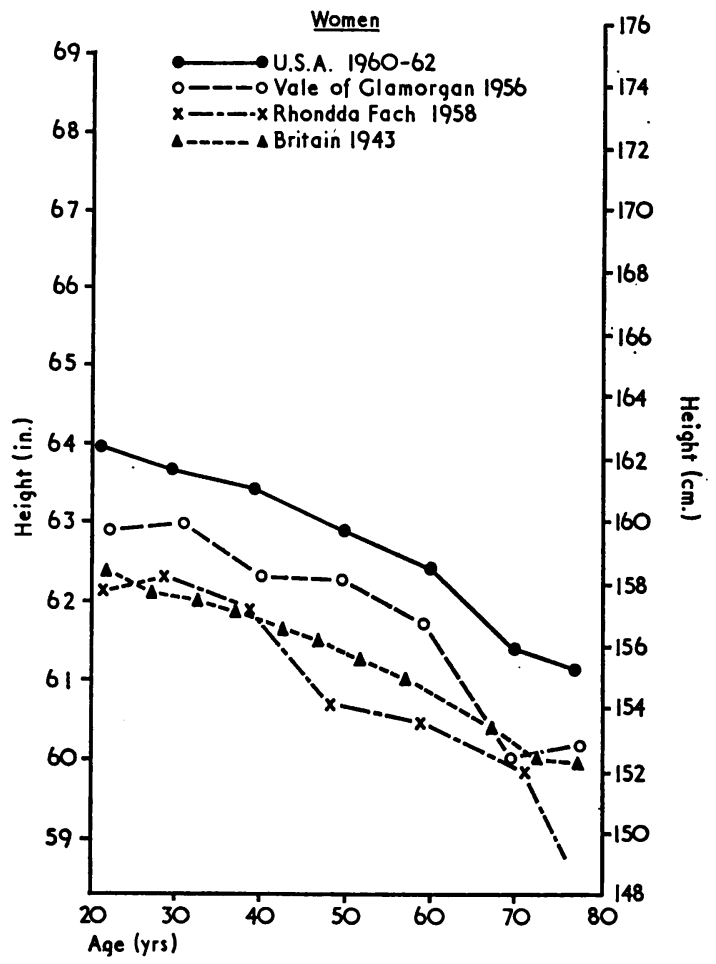

FIG. 2.-Mean heights by age of women in the Vale of Glamorgan (1956), the Rhondda Fach (1958), Great Britain (1943), and U.S.A. (1960-2).

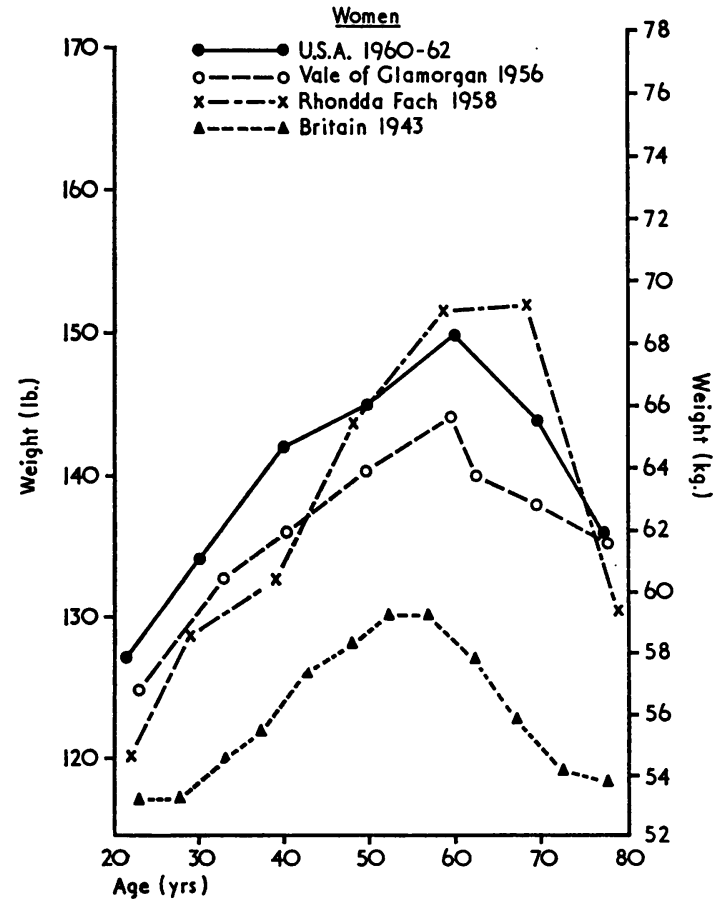

Fig. 4.- Mean weights by age of women in the Vale of Glamorgan (1956), the Rhondda Fach (1958), Great Britain (1943), and U.S.A. (1960-2) 
Illsley, Finlayson, and Thompson (1963) reported that male emigrants from the Rhondda Fach between 1951 and 1955 were on average 0.7 in. taller than those who stayed in the area.

Mean heights declined with increasing age in both Welsh populations, as they have been found to do in most surveys of adult stature. In a further study of heights measured at these and subsequent surveys, this decrease is shown by Miall, Ashcroft, Lovell, and Moore (1967) to be only partly due to the diminishing stature of the individual with age. Other factors, including the attainment of greater height by younger generations, particularly in recent years, are important.

A comparison of the weights of the British, American, and Welsh populations show differences which are similar to those of heights except for the Rhondda Fach women, who, although they were the shortest, were also the heaviest after the age of 50 years. The Rhondda Fach men and women of 60 years were heavier by about $6 \mathrm{lb}$. and $23 \mathrm{lb}$. respectively than those of the same age measured in the British survey of 1943 . For men mean weights rose with age, reaching a maximum between 40 and 50 years, but in women the increase continued later and was greater. Women of mean age 56 in the Rhondda Fach were about $33 \mathrm{lb}$. heavier, although about $1 \frac{1}{2}$ in. shorter than those aged 21. Men of mean age 46 in the Rhondda Fach were $10 \mathrm{lb}$. heavier although they were $1 \frac{1}{2}$ in. shorter than those aged 21 . In the older age groups mean weights declined in both sexes. At 70 years men weighed a few pounds less but women weighed more than those aged 21, both in the Rhondda Fach and in the Vale.

Weight for height at various ages is a more valuable index of stoutness than is weight alone. The number of subjects was too small to permit the Welsh data to be divided into narrow age-height categories, but extremes of height and age were removed by considering the weights of men 63-69 in. tall and women 59-64 in. tall, aged between 35 and 64 years. ( 85 per cent. of men and 77 per cent. of women in the Rhondda Fach in these age groups fell into these height ranges; in the Vale corresponding figures were 81 per cent. of men and 84 per cent. of women.) Table III shows some weight percentiles of these subjects. Outstanding are the weights of the Rhondda Fach women, 10 per cent. of whom weighed more than $190 \mathrm{lb}$. The large proportion of heavy persons in all groups is disquieting because obesity is well known to be associated with an increased mortality risk.

The results reported are cross-sectional and obtained from two localities some time ago. Similar
TABLE III

PERCENTILES OF WEIGHTS (lb.) OF MEN AGED 35-64 YEARS OF HEIGHT 63-69 in. AND OF WOMEN AGED 35-64 YEARS OF HEIGHT $59-64$ in. IN THE RHONDDA FACH, 1958 AND VALE OF GLAMORGAN, 1956

\begin{tabular}{|c|c|c|c|c|c|c|}
\hline \multirow{2}{*}{ Sex } & \multirow{2}{*}{ Locality } & \multicolumn{5}{|c|}{ Percentiles of Weights (lb.) } \\
\hline & & 10 th & 25th & 50th & 75th & 90 th \\
\hline Male & $\begin{array}{l}\text { Rhondda Fach } \\
\text { Vale of Glamorgan }\end{array}$ & $\begin{array}{l}120 \\
130\end{array}$ & $\begin{array}{l}134 \\
142\end{array}$ & $\begin{array}{l}147 \\
156\end{array}$ & $\begin{array}{l}167 \\
176\end{array}$ & $\begin{array}{l}178 \\
194\end{array}$ \\
\hline Female & $\begin{array}{l}\text { Rhondda Fach } \\
\text { Vale of Glamorgan }\end{array}$ & $\begin{array}{l}106 \\
112\end{array}$ & $\begin{array}{l}122 \\
123\end{array}$ & $\begin{array}{l}140 \\
139\end{array}$ & $\begin{array}{l}161 \\
156\end{array}$ & $\begin{array}{l}191 \\
178\end{array}$ \\
\hline
\end{tabular}

results might not be found in other British communities and the position to-day may be different from what it was 10 years ago, although at a later survey in 1964 of the survivors of the same Welsh popula- is tions the weight changes with age resembled those reported here. The surveys will continue and a further analysis of the data, including those of $\mathcal{G}$ mortality, may show the relative importance of 은 higher mortality rates among the obese as a cause of the lower weights of the elderly.

\section{SUMMARY}

(1) Mean heights and weights by age are reporte $\widehat{\varrho}$ of adults living in 1956 in an agricultural area im. the Vale of Glamorgan, and in 1958 in the Rhondda Fach, a mining valley, both in South Wales.

(2) Men in the Rhondda Fach were shorter and lighter than in the Vale. Women in the Rhondda Fach were shorter at all ages but in later life were heavier than in the Vale.

(3) Mean weights were considerably higher than those found in the British national survey of 1943 , and many people, especially middle-aged women in the Rhondda Fach, were overweight.

\section{REFERENCES}

Illsley, R., Finlayson, A., and Thompson, B. (1963), Milbank mem. Fund Quart., 41, 217.

Kemsley, W. F. F. (1950). Ann. Eugen. (Lond.), 15, 161.

Miall, W. E., Ashcroft, M. T., Lovell, H. G., and Moore, F. (1967). Hum. Biol. "A" longitudinal study of the decline of height with age in two Welsh communities" (in press).

- and Oldham, P. D. (1955). Clin. Sci., 14, 459.

- (1958). Ibid., 17, 409.

- (1963). Brit. med. J., 1, 75.

Tanner, J. M. (1962). "Growth at Adolescence", 2nd ed. Blackwell Scientific Publications, Oxford.

U.S. Department of Health, Education, and Welfare (1965). "Vital and Health Statistics", National Center for Health Statistics, Series II, No. 8. PHS Publ. No. 1000. Washington, D.C. 